\title{
Effect of deformation and crystal size of mechanically alloyed and tempered composite tungsten powders with titanium additives on the sintering process
}

\author{
H.Jahangiri, M.L.Ovecoglu
}

\author{
I.T.U. Chemical and Metallurgical Engineering Faculty, Istanbul Technical \\ University, 34469 Maslak/Istanbul, Turkey
}

\section{Received November 19, 2017}

The effect of the deformation and size of crystals of mechanically alloyed and tempered
composite tungsten powders with titanium additives on the sintering process is studied.
For the synthesis of composite powders W-xTi $(x=4.0$ and 10.0 wt. $)$, The mechanical
lloying process was carried out in a SpexTM Duo Mixer/Mill $8000 \mathrm{D}$ under an argon
tmosphere for 20 h. The density and size of the crystallites/powders were measured
efore and after the quenching process. The measurements were carried out by a helical
ycnometer and Lorentz methods in combination with XRD. Sintered bulk composites were
haracterized under the same conditions. Samples made by hardened powders did not fully
ake. The relative density of sintered samples obtained from non-carbon powders was
igher ( $97.19 \%)$. In contrast, samples made from heat-treated powders had smaller
rystallite sizes and lower densities $(80.50 \%)$. It is shown that the preheating of mechani-
ally doped powders adversely affects the sintering of composite powders during the
ompaction process.
Keywords: composite powders, tungsten, mechanical alloying, sintering, strain, crystallite size.

Исследовано влияние деформации и размера кристаллов механически легированных и закаленных композитных порошков вольфрама с титановыми добавками на процесс спекания. Для синтеза композитных порошков $\mathrm{W}-x \mathrm{Ti}(x=4,0$ и 10,0 мас. $\%)$ процесс механического легирования проводили в SpexTM Duo Mixer/Mill 8000D в атмосфере аргона в течение 20 ч. Измерялась плотность и размеры кристаллитов/порошков до и после процесса закалки. Измерения проводились геликовым пикнометром и лоренцевыми методами в сочетании c XRD. Спеченные объемные композиты характеризовались в тех же условиях. Образцы, изготовленные закаленными порошками, полностью не спекались. Относительная плотность спеченных образцов, полученных из неуглеродных порошков, была выше $(97,19 \%)$. Напротив, образцы, изготовленные из термообработанных порошков имели меньшие размеры кристаллитов и более низкие значения плотности $(80,50 \%)$. Показано, что предварительный нагрев механически легированных порошков отрицательно влияет на спекание композитных порошков во время процесса их уплотнения.

Вплив деформації і розміру кристалів механічно легованих і загартованих композитних порошків вольфраму з титановими добавками на процес спікання. H.Jahangiri, M.L.Ovecoglu.

Досліджено вплив деформації та розміру кристалів механічно легованих і загартованих композитних порошків вольфраму з титановими добавками на процес спікання. Для синтезу композитних порошків $\mathrm{W}-x \mathrm{Ti}(x=4,0$ і 10,0 мас.\%) процес механічного легування проведено в SpexTM Duo Mixer/Mill 8000D в атмосфері аргону протягом 
20 год. Виміряно щільність і розміри кристалітів/порошків до і після процесу загартування. Вимірювання проведено геліковим пікнометром i лоренцевими методами у поєднанні з XRD. Спечені об'ємні композити охарактеризовано в тих же умовах. Зразки, виготовлені загартованими порошками, повністю не спікаються. Відносна щільність спечених зразків, отриманих з неуглеродних порошків, вище $(97,19 \%)$. Навпаки, зразки, виготовлені з термооброблених порошків мали менші розміри кристалітів і більш низькі значення щільності $(80,50$ \%). Показано, що попереднє нагрівання механічно легованих порошків негативно впливає на спікання композитних порошків під час процесу їх ущільнення.

\section{Introduction}

Tungsten and its alloys are known as refractory metals, which have a high melting point and a low thermal expansion, the lowest vapor pressure and other defined characteristics for refectory metals [1,2]. However, alloying of monolithic tungsten is mandatory for applications, which require high strengths at elevated temperatures. The reason is mechanical properties of tungsten, which significantly decrease with the temperature increasing [3-8].

Small amounts of transition elements (e.g., $\mathrm{Ni}, \mathrm{Co}$, and $\mathrm{Fe}$ ) during mechanical alloying (MA) activate sintering and enable the fabrication of fully dense tungstenbased alloys and composites at lower temperatures compared to the regular sintering temperatures of tungsten [7-13]. Mechanical milling (MM) and mechanical alloying are complex processes which involve optimization of a number of variables to achieve desired powders [13-15]. During the MM and MA processes, powders solubility, crystallite size, and lattice strain values are significantly changed $[14,15]$. Variation of these parameters can affect the sintering regime to reach the final products with tailored characteristics.

In this study, half part of mechanically milled and mechanically alloyed powders were tempered at $300^{\circ} \mathrm{C}$ for $3 \mathrm{~h}$ and remain powders were used without direct heat treatment. Strain values were measured by the Lorentzian methods before and after the tempering then its effect on the sintering of $\mathrm{W}-x \mathrm{Ti}(x=4.0$ and 10.0 wt. \%) was analyzed.

\section{Experimental}

Elemental tungsten (W) (Eurotungstene ${ }^{\mathrm{TM}}, 99.9 \%$ purity, $45 \mu \mathrm{m}$ average particle size) and titanium (Ti) (Alfa Aesar ${ }^{\mathrm{TM}}$, $99.9 \%$ purity, $45 \mu \mathrm{m}$ average particle size) powders were used in the current study. Crystallite size, and strain of the powders increased by MM so, tungsten powders were pre-milled for $10 \mathrm{~h}$ in a Spex ${ }^{\mathrm{TM}}$ Duo Mixer/Mill 8000D with a speed of $1425 \mathrm{rpm}$ in a tungsten carbide (WC) vial with
$6.35 \mathrm{~mm}$ diameter ( $1 / 4$ inches) WC balls. Loading and unloading of the vials were carried out inside a Plaslabs ${ }^{\mathrm{TM}}$ glove box under purified Ar gas (99.995\% purity) to prevent oxidation during MM. The ball to powder weight ratio (BPR) was 10:1.

The pre-milled $\mathrm{W}$ and elemental Ti powders were blended to constitute the $\mathrm{W}-x \mathrm{Ti}$ ( $x=4.0$ and 10 wt. \%) composition and the powder blends were mechanically alloyed in argon atmosphere (dry milling media), for $20 \mathrm{~h}$ in the Spex ${ }^{\mathrm{TM}}$ Duo Mixer/Mill 8000D using the same conditions used for pre-milling: loading and unloading of the vials were carried out inside the Plaslabs ${ }^{\mathrm{TM}}$ glove box under purified $\operatorname{Ar}$ gas (99.995 \% purity) and BPR was 10:1.

Half part of the mechanically milled and mechanically alloyed powders was tempered at $300^{\circ} \mathrm{C}$ for $3 \mathrm{~h}$ and remaining powders were used without heat treatment.

Microstructural characterizations of the tempered and un-tempered powders were performed using a Bruker ${ }^{\mathrm{TM}}$ D8 Advance $\mathrm{X}$-ray diffractometer (XRD) (CuK $\alpha$ radiation, $\lambda=1.542 \AA$ ). The crystallite size and strain rates were measured and calculated using TOPAS 5 (Bruker AXS) software using the Lorentzian method before and after tempering, then its effect on the sintering of $\mathrm{W}-x \mathrm{Ti}$ powder composites $(x=4.0$ and 10.0 wt. \%) was analyzed. The powder particle size measurements were performed in a Malvern TM Master-sizer Laser particle size analyzer and in a Microtrac ${ }^{\mathrm{TM}}$ NANOflex in-situ particle size analyzer. Densities of the MA W- $x$ Ti powders were measured in helium Pycnometer Micromeritics AccuPyc $^{\mathrm{TM}}$ II 1340.

The produced powders were sintered by Pressureless sintering method (PLS). In PLS methods mechanically alloyed powders were consolidated in a 10 ton capacity APEXTM $3040 / 4$ uniaction hydraulic press to obtain cylindrical mold with a diameter of $12 \mathrm{~mm}$ under $5 \mathrm{MPa}$. Shaped cylinders were sintered in a Linn ${ }^{\mathrm{TM}}$ high temperature hydrogen furnace at $1400^{\circ} \mathrm{C}$ under inert $\mathrm{Ar}$ (introduced between $20-650^{\circ} \mathrm{C}$ and $1100^{\circ} \mathrm{C}-1400^{\circ} \mathrm{C}$ ) and 


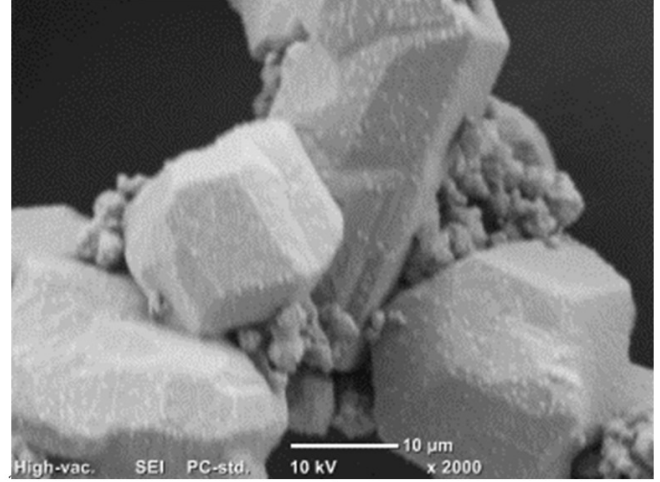

a)

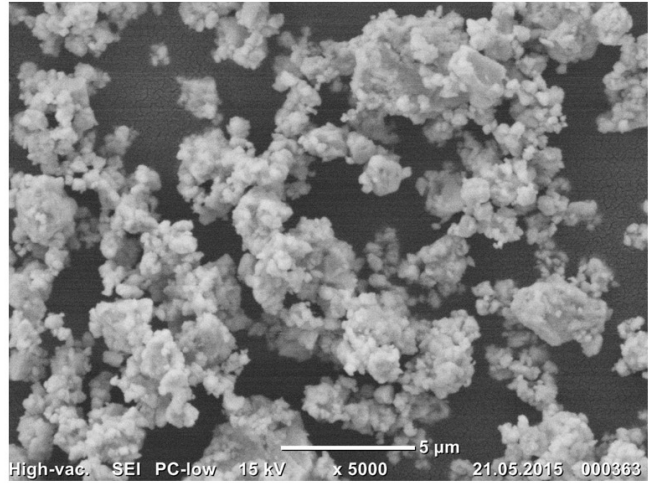

c)

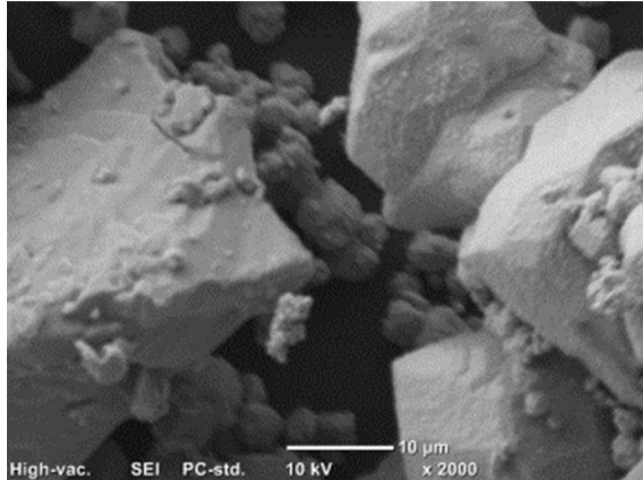

b)

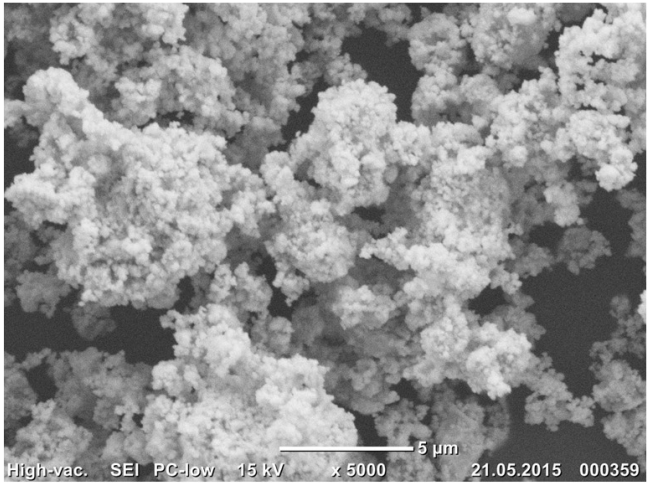

d)

Fig. 1. W and $\mathrm{W}-10.0 \mathrm{Ti}$ powder morphology before and after tempering, a - W before pre-milling $\mathrm{b}-\mathrm{W}-10 \% \mathrm{Ti}$ MA0h, $\mathrm{c}-\mathrm{W}-10.0 \%$ Ti MA20h before tempering, $\mathrm{d}-\mathrm{W}-10.0 \%$ Ti MA20h after tempering.

reducing $\mathrm{H}_{2}$ (introduced between $650^{\circ} \mathrm{C}$ and $1100^{\circ} \mathrm{C}$ ) gas flowing conditions for $1 \mathrm{~h}$.

Microstructural characterizations of the sintered products of $\mathrm{W}-x \mathrm{Ti}$ powders were performed using Bruker ${ }^{\mathrm{TM}}$ D8 Advance X-ray diffractometer (XRD) (CuK $\alpha$ radiation, $\lambda=$ $1.542 \AA)$. The crystallite size and strain rates were measured and calculated using TOPAS 5 (Bruker AXS) software using the Lorentzian method and true densities of the products were measured in helium Pycnometer Micromeritics AccuPyc ${ }^{\mathrm{TM}}$ II 1340.

The structures of the crystal are disrupted both for the mechanical milling and mechanical alloying sintered products. As a result, the defect density increases. The increment of dislocations is correlated with the lattice strain. The obtained diffraction patterns demonstrate imperfections in the material i.e. dislocations, crystallite size, and strains within the grains due to dislocations and stacking faults. The X-ray diffraction peak is broadened due to the small crystallite size and strain owing to dislocations and stacking faults [15-18].

$$
B_{\text {total }}=B_{\text {crystallite }} B_{\text {strain }} \text {, }
$$

where, $B_{\text {total }}$ is total peak broadening; $B$ crystallite and $B_{\text {strain }}$ are peak broadenings due to the crystallite size and lattice strain, respectively. $B_{\text {strain }}$ can be expressed as below.

$$
B_{\text {strain }}=\eta \tan \theta
$$

where $\eta$ is strain in the material and $\theta$ is the peak position [15-18].

The strain is kind of trapped energy in crystal, which can play driving force role in the sintering. This internal energy can be reduced by the heat treatment [16-18].

\section{Results and discussions}

Tungsten (W) as a raw material is premilled. By $10 \mathrm{~h}$ milling of $\mathrm{W}$ powders, average particle size of pre-milled $W$ powders reduced to $0.15 \mu \mathrm{m}$. Figure 1 shows used powders size and morphology.

Figure 1 shows morphological structure of the powders. Figure 1(a) demonstrates W powders before milling: as shown $W$ has polygonal structure with the smooth edges. In Fig. 1(b) $10 \mathrm{~h}$ mechanically milled $\mathrm{W}$ and 

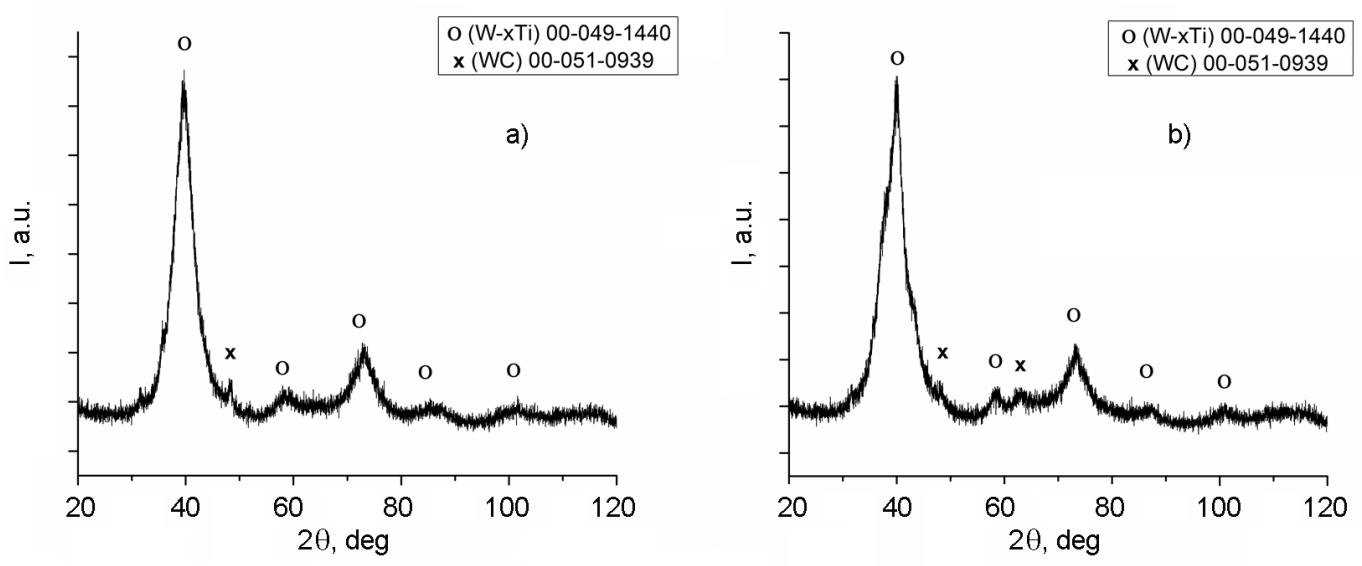

Fig. 2. Mechanically alloyed powder XRD pattern a) - W-10.0 wt. \% Ti mechanically alloyed for $20 \mathrm{~h}$ before tempering, b) - W-10.0 wt. \% Ti mechanically alloyed for $20 \mathrm{~h}$ after tempering.

Table 1. Strain, crystallite size and relative density of $\mathrm{W}-x \mathrm{Ti}(x=4$ and $10.0 \mathrm{wt} . \%)$ mechanically alloyed $20 \mathrm{~h}$ un-tempered and tempered powders

\begin{tabular}{||c|c|c|c||}
\hline & Internal strain (\%) & Crystallite size (nm) & Relative Density (\%) \\
\hline AS-Blended W-10 wt. \% Ti & 1.78 & 20.44 & 86.01 \\
\hline W-4.0 wt. \% Ti MA 20h & 3.97 & 2.10 & 80.45 \\
\hline Tempered W-4.0 wt. \% Ti MA 20h & 0.01 & 3.04 & 81.11 \\
\hline W-10 wt. \% Ti MA 20h & 3.53 & 5.78 & 81.30 \\
\hline Tempered W-10 wt. \% Ti MA 20h & 0.01 & 6.14 & 83.42 \\
\hline
\end{tabular}

10.0 wt. $\% \mathrm{Ti}$ were mixed up, with $\mathrm{Ti}$ that revealed itself in broken shape with the sharp edges. In Fig. 1(c) and (d) the mechanically milled $\mathrm{W}$ powders are presented after $20 \mathrm{~h}$ of MA before and after tempering, respectively. After $20 \mathrm{~h}$ MA the powders were in $0.15 \mu \mathrm{m}$ range. After the tempering, the powders were agglomerated. The powders morphology of was not changed by the heat treatment in $\mathrm{Ar}$ atmosphere.

The XRD patterns of W-xTi $(x=$ 10.0 wt. $\%$ ) before and after the tempering are presented in Fig. 2. The XRD patterns of the MA powders show that $W$ phase has BCC Bravais lattice and Im $3 m$ is the space group of all samples [18]. By applying of MM and MA, not only powders particle size was decreased but also internal strain of $W$ increased, peak broadened and intensity declined [15].

As it can be seen in Fig. 2, only peaks belonging to 00-049-1440 appeared, which are responsible for $\mathrm{W}-x \mathrm{Ti}(\beta \mathrm{W}-\mathrm{Ti}$ phase) formation. $\mathrm{Ti}$ does not show any diffraction peak. W-xTi $(x=10.0 \mathrm{wt} \%)$ peaks before tempering are broader than peaks after tempering at $300^{\circ} \mathrm{C}$. Based on these peaks, it is predictable that internal strain of the tem- pered powders is smaller. After tempering, deformed lattice reformed it led to the peaks got sharper and meantime unseen peaks of WC 00-051-0939 appeared.

As seen in Table 1, after $20 \mathrm{~h}$ of MA, the powder densities and crystallite sizes were decreased while the internal strain values were increased. These measured values show good consistency with the existing literature. Oleszak et al. reported that used conventional horizontal low energy ball mill for W grinding reaching $5.5 \mathrm{~nm}$ [19]. Avettand et al. reached $5 \mathrm{~nm}$ of $\mathrm{W}$ powder by Fritsch Pulverisette 6 TM planetary ball mill [20], while S.Coskun et al. used Spex ${ }^{\mathrm{TM}}$ Duo Mixer/Mill 8000D to reach the finest powder [21]. After tempering at $300^{\circ} \mathrm{C}$ for $3 \mathrm{~h}$, the powders densities and crystallite size increase, and internal strain decreases, reaching $0.01 \%$. Crystallite sizes were increased because of sub-grain rearrangement after the heat treatment [4, 15, 16].

Figure 3 shows the XRD patterns of the samples after sintering at $1400^{\circ} \mathrm{C}$. Comparing of un-tempered and tempered patterns in Fig. 3 confirms that the XRD pattern of the sintered composite produced by un-tempered mechanically alloyed powders were 
Table 2. Strain, crystallite size and relative density of $\mathrm{W}-x \mathrm{Ti}(x=4.0$ and $10.0 \mathrm{wt} . \%)$ MA $20 \mathrm{~h}$ un-tempered and tempered sintered samples

\begin{tabular}{|c|c|c|c||}
\hline & Internal strain (\%) & Crystallite size (nm) & Relative Density (\%) \\
\hline W-4.0 wt. \% Ti MA 20h & 0.01 & 1480 & 97.19 \\
\hline Tempered W-4.0 wt.\% Ti MA 20h & 0.01 & 840 & 80.50 \\
\hline W-10 wt.\% Ti MA 20h & 0.01 & 1355 & 96.58 \\
\hline Tempered W-10 wt.\% Ti MA 20h & 0.01 & 780 & 78.18 \\
\hline
\end{tabular}

more intense and narrower than the samples' fabricated by the tempered powders. Because of this, it can be estimated that the un-tempered group samples were denser and crystallite size got larger. This is in complete agreement with the observations from pycnometer and TOPAS 5 (Bruker AXS) which are shown in Table 2 .

Table 2 shows the relative density of the sintered samples. According to these values the samples fabricated by the tempered mechanically alloyed powders were not sintered completely, while the un-tempered powders sintered. MM and MA applied external force: a part of the energy was trapped in the structure as the lattice strain. During tempering the energy was released and the internal strain of whole samples decreased to 0.01 (see Table 1), approximately equal zero $[16,17]$. The trapped energy helped sintering of the untempered powders during densification process. This can be understood from larger crystallite size of the un-tempered powders. On the contrary, the samples which were fabricated by the heat-treated powders have smaller crystallite size and their density values are lower.

\section{Conclusions}

Based on the current study, the following observations and results can be drawn.

Before and after tempering in Ar atmosphere, morphology of the powders was not changed.

XRD peaks of the $\mathrm{W}-x \operatorname{Ti}(x=10.0$ wt. $\%)$ powders before tempering were broader than peaks after tempering. The appeared peaks got sharper after tempering, meantime unseen peaks of WC appeared simultaneously.

XRD peaks of sintered composite produced by the un-tempered mechanically alloyed powders were more intense and narrower than the samples fabricated by the tempered powders.

MM and MA applied external force to the powders: a part of the energy was trapped

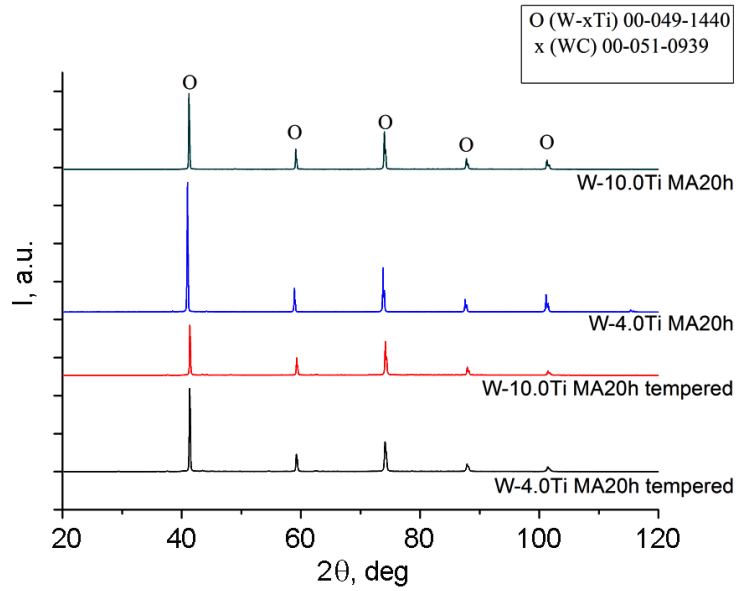

Fig. 3. XRD pattern of sintered samples at $1400^{\circ} \mathrm{C}$ by PLS, a) - W-10.0 wt. \% Ti mechanically alloyed for $20 \mathrm{~h}$ before tempering, b) - W-10.0 wt. \% Ti mechanically alloyed for $20 \mathrm{~h}$ after tempering.

in the lattice structure as the lattice strain. During heat treatment, this energy was released and the internal strain of whole samples decreased to approximately zero.

The samples fabricated by the un-tempered powders were denser than the samples produced by the heat-treated powders.

\section{References}

1. ASM, Production of Refractory Metal Powder, Powder Metal Technologies and Applications, v.7, ASM Handbook, Materials Park , OH, ASM International (1998), p.188.

2. ASM, Refractory Metals, Powder Metal Technologies and Applications, v.7, ASM Handbook, Materials Park, OH, ASM International (1998), p.903.

3. S.G,Caldwell, Tungsten Heavy Alloys, Powder Metallurgy Technologies, v.7, ASM Handbook, Materials Park, OH, ASM International (1998), p.914.

4. R.M.German, A.Bose, S.S.Mani, Metallurgical Trans. A, 23, 211 (1992).

5. R.L.Coble, J. Appl. Phys., 32, 787 (1961).

6. J.L.Johnson, Sintering of Refractory Metals. Sintering of Advanced Materials-Fundamentals and Processes, Woodhead Publishing, Cambridge (2010). 
7. O.V.Tolochko, O.G.Klimova, S.S.Ordanian, D.I.Cheong, Rev.Adv.Mater.Sci, 21, 192 (2009).

8. A.Genc, S.Coskun, M.L.Ovecoglu, Alloys and Comp., 497, 80 (2010).

9. A.G.Hamidi, H.Arabi, \& S.Rastegari, Int.J. Refractory Metals Hard Mater., 29, 538 (2011).

10. Y.Kim, K.H.Lee, E.P.Kim, D.I.Cheong, \& S.H.Hong, Int.J.Refractory Metals Hard Mater., 27, 842 (2009).

11. A.Genc, S.Coskun, M.L.Ovecoglu, Mater. Character., 61, 740 (2010).

12. D.Agaogullari, O.Balci, O.U.Demirkan, H.Gokce, in: Solid State Phenomena, v.194, Trans. Tech. Publ. (2013), p.194.

13. H.Jahangiri, S.Sonmez, \& M.L.Ovecoglu, Indian J. Mater. Sci. (2016). http://dx.doi.org/10.1155/2016/7981864
14. H.Jahangiri, M.L.Ovecoglu, Mater. Lett., 178, 193 (2016).

15. C.Suryanarayana, Progr. Mater. Sci., 46, 1 (2001).

16. C.Suryanarayana, Mechanical Alloying and Milling, CRC Press, New York (2004).

17. W.H.Bragg, \& W.L.Bragg, Proc.Royal Soc. London. Ser. A, Containing Papers Mathem. Phys. Character, 88, 428 (1913).

18. Powder Diffraction files: Card No. 04-0806, Database Edition, The International Centre for Diffraction Data (ICDD).

19. D.Oleszak, P.H.Shingu, J. Applied Phys., 79, 2975 (1996).

20. M.N.Avettand-Fenoel, R.Taillard, J.Dhers, J.Foct, Int.J. Refractory Metals Hard Mater., 21, 205 (2003).

21. S.Coskun, M.L.Ovecoglu, Int.J.Refractory Metals Hard Mater., 29, 651 (2011). 